\title{
ASPECTOS PRÁTICOS DA SUCESSÃO DOS COMPANHEIROS SEPTUAGENÁRIOS APÓS DECLARAÇÃO DE INCONSTITUCIONALIDADE DO ARTIGO 1790 DO CÓDIGO CIVIL
}

\author{
Rosemary Cipriano da Silva ${ }^{1}$ \\ Raphael Swerts Silva ${ }^{2}$
}

\section{RESUMO:}

A partir da declaração de inconstitucionalidade do artigo 1790 do Código Civil pelo Supremo Tribunal Federal determinando a aplicação das regras do casamento à união estável, retoma-se a discussão acerca da possibilidade de equiparação das formas de família constitucionalizadas e aplicação analógica de regras restritivas de direitos previstas para o casamento à união estável, mormente, a imposição do regime de separação obrigatória de bens. O objetivo da presente pesquisa é analisar a aplicação prática das regras sucessórias do casamento à união estável, com ênfase na união estável dos septuagenários.

PALAVRAS-CHAVE: Direito das SucessõesUnião; Estável Companheiros; Septuagenários; Inconstitucionalidade; Código Civil

\section{PRACTICAL ASPECTS OF SUCCESSION OF SEPTUAGENARY FELLOWS AFTER STATEMENT OF CIVIL CODE 1790 UNCONSTITUTIONALITY}

\begin{abstract}
:
From the declaration of unconstitutionality of article 1790 of the Civil Code by the Federal Supreme Court determining the application of marriage rules to the stable union, the discussion on the possibility of equalizing constitutionalized family forms and analogous application of restrictive rights rules is resumed. provided for the marriage to the stable union, especially the imposition of the compulsory separation of property regime. The aim of the present research is to analyze the practical application of the succession rules of marriage to stable union, with emphasis on the stable union of the septuagenarians.
\end{abstract}

KEYWORDS: Succession Law Stable; union; Septuagenarian; Companions; Unconstitutionality; Civil Code

\section{INTRODUÇÃO}

Após declaração de inconstitucionalidade do artigo 1790 do Código Civil pelo Supremo Tribunal Federal, passou-se a aplicar as regras da sucessão do cônjuge aos casos de

\footnotetext{
${ }^{1}$ Mestra em Direito pela Universidade FUMEC (2010). Graduada em Direito pela Universidade FUMEC (2007). Mediadora certificada pelo Tribunal de Justiça de Minas Gerais.

${ }^{2}$ Graduado em Direito pela Dom Helder Câmara (2011). Pós-graduado em Direito Civil pela PUC-MG (2016) e Mestre em Políticas Públicas pelo Centro Universitário Una (2018).
} 
união estável. Diante dessa nova realidade, retoma-se a questão acerca da aplicação generalizada das regras do casamento à união estável. De forma delimitada, o presente estudo visa analisar a aplicação do regime de separação obrigatória de bens nos casos de união estável dos septuagenários em razão das divergências jurisprudenciais e doutrinárias acerca do tema, e, especialmente, ante a insegurança jurídica à qual nos depararíamos nos casos de sucessão quando da aplicação das regras do casamento à união estável, especialmente, nos casos de concorrência do companheiro com os descendentes do autor da herança.

Necessário nos debruçar, portanto, à possibilidade de aplicação à união estável entre pessoas maiores de setenta anos, da regra contida no artigo 1641, II que prevê o regime de separação obrigatória no casamento de pessoas maiores de setenta anos. A questão não é pacificada em razão de tratar-se de formas de famílias distintas: casamento e união estável.

A partir do status constitucional de família conferido à união estável, travou-se discussão doutrinária e jurisprudencial acerca da possível equiparação da união de fato ao casamento, até então a única forma de família reconhecida pela Constituição.

À margem dessa possível equiparação, o legislador infraconstitucional elaborou regras específicas para regulamentar essa forma de família prevista no parágrafo terceiro do artigo 226 da Constituição da República Brasileira.

Nesse diapasão, o Código Civil de 2002 regulou de forma distinta as duas formas de família no Livro IV: Do Direito de Família. Não obstante o tratamento diferenciado atribuído à união estável e ao casamento, a jurisprudência majoritária entende pela equiparação dessas formas de família e pela possibilidade de aplicação das normas previstas para o casamento à união estável.

Nosso objetivo, portanto, é demonstrar os aspectos práticos de aplicação das regras da sucessão do cônjuge à união estável, mormente quanto às uniões de maiores de setenta anos. Buscaremos, ainda, contrapor as regras atinentes ao direito de família (regime de bens no casamento e união estável entre septuagenários) às regras sucessórias após a declaração de inconstitucionalidade do artigo 1790 do Código Civil, demonstrando-se a insegurança jurídica gerada ante a ausência de consenso jurisprudencial e doutrinário relativamente à imposição do regime de separação obrigatória de bens na união estável das pessoas maiores de setenta anos

Parece-nos que a questão decorre do equívoco em que se incorre, ao buscar aplicar normas elaboradas para regular um instituto (casamento), à outro (união estável), desvirtuando, assim, as formas de família reconhecidas pela Constituição e gerando 
insegurança jurídica.

Para tanto, identificamos as atuais formas de família e apontamos as diferenciações existentes entre elas, bem como a visão da doutrina e da jurisprudência acerca da possível equiparação dessas formas de família. Após, tratamos do regime de bens na união estável e perquirimos acerca da possibilidade de aplicação à essa forma de família, do regime de separação obrigatória de bens às pessoas maiores de setenta anos que constituem união estável, regra elaborada para regular as relações decorrentes do casamento. Por fim, nos debruçamos à questão da sucessão do companheiro maior de setenta anos e consectária aplicação da regra contida no artigo 1829, I que veda a sucessão do cônjuge casado sob o regime de separação obrigatória de bens quando concorre com descendentes do autor da herança, buscando demonstrar as divergências que podem decorrer da aplicação dessa regra.

Concluímos a pesquisa apontando a insegurança jurídica e as disparidades decorrentes da aplicação das regras sucessórias do casamento à união estável, mormente ante as divergências jurisprudências quanto ao regime de bens na união estável de maiores de setenta anos.

Justifica-se a pesquisa em razão da recente declaração de inconstitucionalidade do artigo 1790 pelo STF no julgamento dos Recursos Extraordinários 878.694/MG e 646.721/RS que determinou a aplicação da regra da sucessão do cônjuge contida no artigo 1829, I à união estável, sendo certo que, na prática, haverá disparidades relativamente à sucessão do companheiro maior de setenta anos a depender da interpretação quanto ao regime de bens que deverá ser adotado na união estável dos septuagenários.

A metodologia utilizada foi a teórico bibliográfica por meio da análise de legislação, jurisprudências e doutrinas acerca do tema.

\section{CASAMENTO E UNIÃO ESTÁVEL: FORMAS DE FAMÍLIA EQUIPARADAS PELA CONSTITUIÇÃO?}

O casamento é um instituto tão antigo quanto o próprio ser humano (FARIAS e ROSENVALD, 2011, p. 138) e foi até tempos recentes, a única forma de família reconhecida pelo Estado. Houve época em que sua finalidade maior era a procriação, no intuito de continuação da espécie, além de legitimar a atividade sexual. 
Atualmente o casamento tem como finalidade precípua a comunhão plena de vidas entre pessoas ligadas pelo afeto. Nesse diapasão, o artigo 1511 do Código Civil de 2002 definiu casamento como o estabelecimento de comunhão plena de vidas, com base na igualdade de direitos e deveres dos cônjuges.

A partir dos caracteres e finalidades matrimoniais, Caio Mário da Silva Pereira definiu casamento como "a união de duas pessoas de sexo diferente, realizando uma integração fisiopsíquica permanente" (PEREIRA, 2019, p. 83). É certo, entretanto, que a diversidade de sexos já foi ultrapassada desde o reconhecimento das famílias homoafetivas pelo Supremo Tribunal Federal em 2011.

Para além da histórica importância do casamento na constituição da família, o atual modelo constitucional veio regular outras formas de família não matrimonializadas que conviviam no seio da sociedade, mas que, não recebiam proteção do Estado, ou seja, estavam à margem do direito.

Na vigência do Código Civil de 1916, as uniões livres, ou uniões de fato eram denominadas concubinato ${ }^{3}$, e, independentemente de tratar-se de adultério ou união entre pessoas desimpedidas para o casamento, eram repudiadas pelo ordenamento jurídico que não lhes dispensava qualquer proteção. Isso se explica pelo estigma do adultério e a incondicional proteção à instituição familiar decorrente do casamento como única forma de família (TEPEDINO, 2008, p. 396).

A doutrina, entretanto, tratou de distinguir o concubinato puro - referente às pessoas não impedidas de se casar, mas que optavam pela constituição da família através da união de fato, ou seja, sem interferência estatal - do impuro - decorrente de relação adulterina ou incestuosa.

A partir da promulgação da Constituição da República de 1988 foi reconhecida, enfim, como forma de família, a união estável entre homem e mulher com objetivo de constituir uma família, e o termo concubinato passou a designar as uniões de fato impuras decorrentes de adultério ou relações incestuosas. Como bem esclarece Rodrigo da Cunha Pereira (2003, p. 31), "o gênero família comporta várias espécies, como a do casamento, que maior proteção recebe do Estado" e que tanto o casamento, quanto as outras formas de família

\footnotetext{
3 "Etimologicamente, concubinato significa comunhão de leito". "Origina-se da expressão latina cum (com), cubare (dormir), concubinatus, significando o estado de mancebia, a companhia de cama" (FARIAS e ROSENVALD, 2011, p. 454).
} 
constitucionalmente reconhecidas, "vêm exprimir a liberdade dos sujeitos de constituírem a família da forma que lhes convier, no espaço de sua liberdade" (PEREIRA, 2003, p. 32).

Após a entrada em vigor do texto constitucional, o legislador ordinário aprovou duas leis que objetivaram regulamentar as uniões estáveis. A Lei 8.971 de 1994 e a Lei 9.278 de 1996. Estas leis receberam inúmeras críticas da doutrina devido a imperfeições e, até mesmo, contradições que encerram. Entretanto, segundo Rodrigo da Cunha Pereira, os ataques disparados contra essas leis transcendem o aspecto jurídico:

Ela incomoda porque interfere em dois setores importantes da vida do cidadão: o econômico e o sexual. No econômico, a propriedade deixa de ser exclusiva e pode ser dividida com aqueles que não têm o status de esposa (o). No sexual, porque deverão olhar para uma sexualidade concebida culturalmente como ilegítima (PEREIRA, 2003, p. 52)

Não obstante o reconhecimento da união estável como forma de família, resta claro que a Constituição privilegiou o casamento em relação àquela, o que é nítido ao analisar o dispositivo constitucional esculpido no artigo 226, parágrafo $3^{\circ}$, segundo o qual, para efeito de proteção do Estado, é reconhecida a união estável entre o homem e a mulher como entidade familiar, devendo a lei facilitar sua conversão em casamento.

À margem da nítida distinção destacada pelo texto constitucional, a jurisprudência, não raro, vem fazendo tremenda confusão ao tentar equiparar união estável ao casamento ato jurídico solene rigidamente regulado pelo codex civil - ao passo que aquela é uma união de fato, que se consuma através da convivência pública e duradoura de pessoas não impedidas de se casar que querem constituir família, mas que não desejam a extrema intervenção do Estado em suas vidas. Sobre o tema, colaciona-se o acórdão proferido pela $6^{\text {a }}$ Câmara Cível do Tribunal de Justiça de Minas Gerais:

É obrigatória a adoção do regime da separação obrigatória de bens aos casamentos realizados por pessoas maiores de 60 (sessenta) anos, nos termos do art. 1.641 do Código civil, incidindo a restrição sobre a união estável, iniciada após tal limite etário (...) Equiparando-se a união estável ao casamento, por força constitucional, a disposição do referido artigo também deve ser aplicada aos casos em que o relacionamento intuitu familiae tenha sido iniciado após o implemento da idade por um dos cônjuges. Isso porque o ordenamento jurídico confere aos dois institutos equivalência no que toca aos direitos e obrigações. Por isso, no caso em apreço, devem ser aplicadas ao período de relacionamento informal das partes, antes do casamento ocorrido em 2004, as mesmas regras do casamento, em razão da equiparação estabelecida pela lei para todos os fins de direito, diante da prova de que o convívio tenha iniciado 
após os 60 anos do apelante. (grifamos) (MINAS GERAIS. Tribunal de Justiça. Apelação Cível nº 1.0702.06.317911-4/001, Sexta Câmara Cível, Rel. Sandra Fonseca, 2011).

Percebe-se, claramente, que o citado acórdão não hesita em atribuir os efeitos decorrentes do casamento à união estável estabelecida no curso da vida em comum. Ora, os companheiros por certo não desejam a intervenção do Estado na união não formalizada, mas pública e duradoura estabelecida por eles. Caso contrário, casar-se-iam. As pessoas são livres para escolherem, como melhor lhes convier, a forma de família que desejam constituir.

Em total consonância com esta idéia de liberdade na constituição da família, Rodrigo da Cunha Pereira (2003, p. 52) ressalta que as leis que visaram regulamentar as uniões estáveis pecaram "por demarcarem um campo que, por sua natureza não pode ser demarcado" e que a união estável pertence ao campo do "não instituído". Ainda segundo o autor, "além de não-instituído, esse espaço é e sempre será cheio de contradições” (PEREIRA, 2003, p. 52).

Com efeito, as pessoas que optam pela constituição de família através da união estável almejam a liberdade nesta constituição e não a intervenção do Estado em suas vidas, ou seja, desejam regular livremente a forma de constituição e condução, e, se for o caso, dissolução dessa família. Caso contrário, optariam pelo casamento. O dever do Estado é reconhecê-las como forma de família e protegê-las.

Ora, reconhecer as uniões estáveis como forma de família não é o mesmo que dizer que são equivalentes ao casamento, mas sim que foram acolhidas pela Constituição, recebendo desta, especial proteção enquanto espaço do desenvolvimento pessoal de seus membros.

Nesse sentido Gustavo Tepedino (2008, p. 404) nos esclarece que após a Constituição de 1988 duas correntes se formaram na doutrina e jurisprudência em torno da união estável: uma que entende que devem ser equiparados os direitos decorrentes da família formada pelo casamento aos daquelas resultantes de união estável e outra que entende que a proteção do Estado aos companheiros visou corrigir o erro da negativa de proteção ao concubinato puro "sem que tal tutela representasse a pretendida equiparação com o casamento" (TEPEDINO, 2008, p. 404).

Considerando esta proteção constitucional conferida à união estável, as medidas protetoras constitucionalmente conferidas ao casamento "devem aproveitar também às uniões não formalizadas, mas estáveis, entre homem e mulher ${ }^{4}$ as quais se consideram, para esse fim, como entidades

\footnotetext{
${ }^{4}$ Importante frisar, entretanto, que, há anos a união estável não requer sexos diversos para sua configuração. Com efeito, desde o julgamento da Ação Direta de Inconstitucionalidade (ADI) 4277 e a Arguição de Descumprimento de Preceito Fundamental (ADPF) 132, em 2011, pelo Supremo Tribunal Federal, passou-se a reconhecer a união estável também entre casais homoafetivos, aplicando-se a proteção das normas do direito
} 
familiares" (TEPEDINO, 2008, p. 406). Mas daí dizer-se que a norma atribui aos companheiros situação jurídica totalmente comparada ao casamento, "medeia longa distância" (TEPEDINO, 2008, p. 406).

Outro argumento, a sustentar a mesma tese, foi levantado por José Carlos Barbosa Moreira citado por Gustavo Tepedino (2008, p. 406) segundo o qual o legislador constituinte atribuiu ao legislador ordinário a tarefa de facilitar a conversão da união estável em casamento. Ora, se as duas figuras estivessem igualadas, não faria sentido converter a união estável em casamento. Afinal, "não se pode converter uma coisa em outra, a menos que sejam desiguais: se já são iguais, é desnecessária - e inconcebível - a conversão" (TEPEDINO, 2008, p. 406). Conclui-se, portanto, que a Constituição "não pretendeu equiparar entidades heterogêneas, identificando a relação familiar de fato com o mais solene dos atos jurídicos" (TEPEDINO, 2008, p. 407).

Diante da não equiparação constitucional dessas formas de família, entendemos pela impossibilidade de aplicação das regras legais concernentes ao casamento à união estável, até porque, se fosse essa a intenção do legislador, não haveria elaborado regras específicas para regular as uniões estáveis, bastaria um artigo dizendo que as normas referentes ao casamento são aplicáveis àquela entidade familiar, nada mais.

Não obstante, imperioso reconhecer que a regra sucessória estampada no artigo 1790 do Código Civil que regulava a sucessão dos companheiros sofria de flagrante inconstitucionalidade em razão da desproteção do companheiro na concorrência com familiares do autor da herança. A regra sofria de vários erros, inclusive quanto ao local, figurando no livro de sucessão em geral. Diante de tamanha falta de técnica e preconceito acerca da sucessão do companheiro regulada no artigo 1790 do Código Civil, a doutrina e jurisprudência, não raro, opinava pela não aplicação da referida regra de sucessão do companheiro.

Ocorre que quando da declaração da inconstitucionalidade do referido artigo, o STF nos Recursos Extraordinários 878.694/MG e 646.721/RS determinou a aplicação das regras do casamento à união estável em razão de não haver outra possibilidade ante a inexistência de outras regras aplicáveis à espécie, conforme abaixo será analisado.

3. O CASAMENTO E A UNIÃO ESTÁVEL DE PESSOAS MAIORES DE SETENTA ANOS E A (IM)POSSIBILIDADE DE APLICAÇÃO DA REGRA CONCERNENTE AO CASAMENTO À UNIÃo ESTÁVEL

Por disposição do artigo 1725 do Código Civil de 2002, aplica-se à união estável, de família aos casais que se uniam com animo de constituir família, independente de sexo.

Revista de Direito de Família e Sucessão | e-ISSN: 2526-0227 | Belém | v. 5 | n. 2 | p. 01 - 18 | Jul/Dez. 2019. 
no que couber, o regime de comunhão parcial de bens. Esta regra já se aplicava anteriormente à entrada em vigor do atual codex civil por previsão da Lei 8.971/94 e 9.278/96. É certo que a Lei 8.971/94 não estabeleceu o regime de bens na união estável. Entretanto, previu possibilidade de meação em caso de morte de um dos companheiros, em relação aos bens adquiridos com a colaboração do outro (art. $3^{\circ}$ ). Portanto, se havia direito à meação quando do término da união por morte de um dos companheiros, não haveria motivo para não se proceder à meação quando da dissolução da união estável em vida. Frisese, entretanto, que o direito à meação dependia da colaboração do companheiro na aquisição dos bens. Aqui, por disposição legal, não havia presunção de esforço comum na aquisição do patrimônio.

Já a Lei 9.278/96, dispôs expressamente que os bens imóveis adquiridos na constância da união estável e a título oneroso, seriam considerados fruto do trabalho e colaboração comuns, ou seja, aquestos. Não há que se discutir, portanto, o esforço comum na aquisição do patrimônio, o que o equipara ao regime de comunhão parcial de bens - regime supletivo legal no casamento desde a edição da Lei do divórcio, Lei 6.515/77. É nítida a tentativa do legislador em atribuir à união estável direitos semelhantes aos decorrentes do casamento, ao menos no que concerne ao regime de bens, o que é justificável porquanto são formas de família reconhecidas pela Constituição. Mas isso não autoriza, nem de longe, a aplicação das regras de uma à outra.

O Código Civil de 2002 regulou toda a matéria concernente à união estável, derrogando, dessa forma, as leis que a regulamentavam ${ }^{5}$. Interessa-nos, especialmente, a norma extraída do artigo 1725 do Código Civil que dispõe sobre o regime de bens na união estável, informando que na união estável, salvo contrato escrito entre os companheiros, aplica-se às relações patrimoniais, no que couber, o regime de comunhão parcial de bens.

Identifica-se de início que o regime de comunhão parcial de bens é regime "supletivo" diante da possibilidade de contrato dispondo de forma diversa - pacto de convivência.

\footnotetext{
${ }^{5}$ Esclareça-se que antes da declaração de inconstitucionalidade do artigo 1790 do Código Civil, não havia consenso doutrinário e jurisprudencial acerca da revogação das citadas leis que, não raro, eram aplicadas no intuito de proteger o companheiro (a) supérstite diante do esdrúxulo, contraditório e confuso tratamento dedicado à sucessão dos companheiros no revogado artigo 1790 do Código Civil que os colocava em situação pior que as leis que vieram, após a Constituição de 1988, regulamentar a união estável.
} 
Ressalta-se a importância, no presente estudo, da expressão "no que couber", o que leva à presunção de que nem sempre, na ausência do pacto de convivência, aplicar-se-á o regime de comunhão parcial de bens. Entretanto, o capítulo do Código Civil que regula a união estável não introduziu nenhum dispositivo a fazer qualquer ressalva em relação a aplicação do regime estipulado no artigo 1725, ou seja, regime de comunhão parcial de bens.

Nessa perspectiva, a jurisprudência vem entendendo que não cabe o regime de comunhão parcial de bens nas uniões de pessoas maiores de setenta anos ${ }^{6}$, aplicando, por analogia à regra esculpida no artigo 1641, II do Código Civil, o regime de separação obrigatória de bens. Nesse sentido:

\begin{abstract}
AGRAVO DE INSTRUMENTO. Irresignação em face da decisão que em ação de inventário deferiu o requerimento formulado pela companheira do de cujus, determinando a reserva de bens suficientes para garantia de seus direitos sucessórios a serem definidos. Descabimento. O de cujus possuía idade superior a 70 anos quando do início da união estável, de modo que, por equivalência ao disposto na legislação pátria em relação ao matrimônio, aplica-se o mesmo regramento ao instituto em questão. Sendo o falecido septuagenário quando do início da união estável, o regime de bens vigente é o da separação obrigatória, o qual não permite a concorrência do cônjuge com os descendentes na sucessão legítima. Inteligência do art. 1.829, I, CC. Recurso provido. (SÃO PAULO, Tribunal de Justiça. Agravo de Instrumento ${ }^{\circ}$ 2230760-84.2018.8.26.0000. $5^{\mathrm{a}}$ Câmara de Direito Privado, Rel. James Siano, julgado em 12.02.2019).
\end{abstract}

Coaduna do mesmo entendimento o Tribunal de Justiça de Minas Gerais:

EMENTA: AGRAVO DE INSTRUMENTO - UNIÃO ESTÁVEL - PARTILHA DE BENS - UNIÃO ESTÁVEL ESTABELECIDA COM SEPTUAGENÁRIO APLICAÇÃO DO REGIME DE SEPARAÇÃO TOTAL DE BENS - RECURSO A

QUE SE NEGA PROVIMENTO. A jurisprudência do col. Superior Tribunal de Justiça firmou entendimento no sentido de ser aplicável a obrigatoriedade do regime de separação de bens no casamento da pessoa maior de 60 (sessenta) anos - art. 1.641, inc. II, do Código Civil, alterado para 70 (setenta) anos pela Lei $\mathrm{n}^{\mathrm{o}}$ 12.344/2010 -, às uniões estáveis, observado, porém, o disposto na Súmula 377 do exc. Supremo Tribunal Federal. (Minas Gerais. Tribunal de Justiça. Agravo de Instrumento $n^{\circ}$ 1.0216.13.004121-5/001, $7^{\text {a }}$ Câmara Cível, Rel Des. Belizário de Lacerda. julgado em 10.03.0015, publicado em 17.03.2015)

A lei não prevê a aplicação dessa "penalidade" de regime obrigatório de bens à

\footnotetext{
670 anos a partir de 9 de dezembro de 2010, por força da Lei12.344/10. Na redação original do Código Civil de 2002, essa idade era de sessenta anos.
} 
união estável. Ainda assim, os nossos tribunais aplicam-na. Há vários argumentos notoriamente contrários a essa prática reiterada nos tribunais. Em primeiro lugar, ressalta-se a impossibilidade de interpretação extensiva de normas restritivas de direitos. Ora, se a lei não prevê expressamente a obrigatoriedade de regime, o mesmo não pode ser aplicado, principalmente porque cerceia o direito fundamental de liberdade constitucionalmente assegurado, revelado, aqui, na liberdade de escolha do regime de bens.

Em segundo lugar, ao se aplicar à união estável regra concernente ao casamento, estar- se-á a equiparar formas de famílias não igualadas pela Constituição. Nesse sentido, a lição de Cristiano Chaves de Farias e Nelson Rosenvald:

\footnotetext{
Em nenhum momento se pretendeu igualar os tipos de relação familiar, até porque o casamento é união solene e formal, por instrumento público (produzindo, por isso, efeito erga omnes), enquanto a união estável é uma união livre, não solene e informal, surtindo consequências, tão somente, entre as partes interessadas (FARIAS e ROSENVALD, 2011 p. 297).
}

Em acórdão acerca da possibilidade de aplicação das regras concernentes à sucessão dos cônjuges à sucessão dos companheiros, a oitava Câmara do Tribunal de Justiça do Rio Grande do Sul, entendeu, de maneira diversa, pela não possibilidade da aplicação, tendo em vista a não equiparação das formas de família pela Constituição:

(...) é que não há equiparação constitucional entre a união estável e o casamento, e que também o legislador, no Código Civil, valendo-se da Constituição Federal, tratou diferentemente os dois institutos - união estável e casamento, sendo uma escolha do legislador. (RIO GRANDE DO SUL. Tribunal de Justiça. Agravo de Instrumento $N^{\circ}$ 70017169335. Oitava Câmara Cível, Rel. José Ataídes Siqueira Trindade, 2010).

Percebe-se, ainda, enorme contradição nos julgamentos, visto que o mesmo tribunal e, muitas vezes, a mesma Câmara (ou Turma), entende, hora pela equiparação das formas de família, hora o contrário.

Por outro lado, revela-se a liberdade de escolha da forma de família adotada pelo casal. Ora, aquele que não se casa, sem que para isso haja impedimento, não pretende a intervenção do Estado na forma de constituição, condução e dissolução da união contínua estabelecida com seu consorte. Rodrigo da Cunha Pereira (2003, p. 31/32), há muito já ressaltara que tanto o casamento, quanto as outras formas de família constitucionalmente 
reconhecidas, "vêm exprimir a liberdade dos sujeitos de constituírem a família da forma que lhes convier, no espaço de sua liberdade". A união estável é união não formalizada, pública e duradoura com objetivo de constituir família, mas livre das formalidades e solenidades que envolvem o casamento, e, como bem disse Rodrigo da Cunha Pereira (2003, p. 52) "as uniões de fato pertencem ao campo do não instituído".

Por consectário, não é razoável aplicar-se à união estável regras específicas elaboradas para regular o casamento, visto serem formas de família não igualadas pela Constituição. Diga-se, ainda, que esta diferenciação, entre casamento e união estável, foi respeitada pelo legislador ordinário, ao disciplinar, de forma independente e com regras próprias, as duas formas de família constitucionalmente estabelecidas. Inaceitável, portanto, a extensão da regra de regime obrigatório de separação de bens, elaborada para regular o casamento de pessoas maiores de setenta anos (originariamente sessenta), à união estável.

Diante de todo exposto, percebe-se enorme equívoco dos nossos tribunais ao entender pela extensão dessa regra concernente ao casamento às uniões de fato. Entretanto, após a declaração de inconstitucionalidade do artigo 1790 do Código Civil que regulava a sucessão do companheiro, não restou alternativa ao Supremo Tribunal Federal senão determinar a aplicação das regras sucessórias do casamento à união estável, especialmente, o artigo 1829, I. Nesse ponto, a questão carece de exame mais detido, pois, se é verdade que entendemos pela não aplicação das regras do casamento à união estável quanto ao regime de bens, também é verdade que a não aplicação das regras do casamento à união estável quanto ao quanto ao regime de bens proporcionará distorções e incongruências quando da aplicação das regras sucessórias do casamento à união estável (conforme determinado no julgamento dos Recursos Extraordinários 878.694/MG e 646.721/RS), mormente nos casos de união estável dos maiores de setenta anos, conforme abaixo passa-se a analisar.

\section{A SUCESSÃO DO COMPANHEIRO APÓS A DECLARAÇÃO DE INSCONTITUCIONALIDADE DO ARTIGO 1790 DO CÓDIGO CIVIL}

O julgamento dos Recursos Extraordinários 878.694/MG e 646.721/RS pelo STF em maio de 2017 pôs fim à discussão que se arrastava há anos acerca da inconstitucionalidade do artigo 1790 do Código Civil que regulava a sucessão do companheiro de forma totalmente 
adversa da sucessão do cônjuge. A maioria dos ministros daquela corte entendeu pela inconstitucionalidade da referida regra legal.

A partir do julgamento, estendeu-se aos companheiros o mesmo tratamento legal aplicado aos cônjuges no que concerne à sucessão do convivente falecido. Nesse ponto, merece análise mais cuidadosa a situação de sucessão do companheiro concorrendo com herdeiros da primeira classe, os descendentes. Nos termos do artigo 1829, inciso I, do Código Civil, o cônjuge (agora também o companheiro) participa da sucessão do outro em concorrência com os descendentes, exceto se casado com o de cujos nos regimes de comunhão universal de bens, separação obrigatória e comunhão parcial em que o autor da herança não houver deixado bens particulares.

A exclusão do cônjuge da herança do falecido no regime de comunhão universal de bens encontra respaldo no direito de meação sobre todo o patrimônio deixado pelo autor da herança. A mesma regra vale para os casos de comunhão parcial em que o autor da herança não deixar bens particulares, pois, da mesma forma, todo o patrimônio será comum e o cônjuge sobrevivente terá direito à metade de todo o patrimônio.

Entretanto, a exclusão da herança do cônjuge casado no regime de separação obrigatória de bens visa apenas resguardar direitos aos descendentes em razão da penalidade legal imposta no artigo 1641 do Código Civil para aqueles que se casarem com necessidade de autorização judicial (como forma de suprimento da autorização dos pais) ${ }^{7}$, para aqueles que se casarem em infringência às causas suspensivas e para os maiores de 70 (setenta) anos. Nesses casos, independentemente de existir direito à meação do patrimônio (o que pode ocorrer, quanto aos aquestos, por força da aplicação da Súmula 377 do STF), o cônjuge sobrevivente não terá direito à herança do falecido.

Percebe-se, portanto, que o motivo da exclusão da herança nos casos de separação obrigatória de bens encontra respaldo na necessidade de manter coerência entre as regras do Direito de Família e do Direito das Sucessões. Com efeito, a obrigatoriedade do regime de separação de bens prevista no artigo 1641 do Código Civil impõe uma penalidade àqueles que se casarem nas circunstâncias previstas na regra legal. Portanto, as regras atinentes à sucessão não poderiam deixar de repetir tais penalidades sob pena de se tornar inócua a penalidade

\footnotetext{
${ }^{7}$ Após edição da lei 13.811/2019 não mais é permitido o casamento de menores de 16 anos, portanto, a única hipótese de casamento com autorização judicial concerne aos casos em que os genitores detentores do poder familiar, ou um deles, não autorizam o casamento do menor entre 16 e 18 anos.
} 
imposta no artigo 1641 do Código Civil. Explica-se. Nos casos em que os cônjuges casados sob o regime de separação obrigatória não adquirirem bens na constância do casamento, não haverá meação. Entretanto, caso não houvesse a vedação de participação na sucessão em concorrência com os descendentes (artigo 1829, I), o cônjuge não receberia meação, mas receberia herança quanto aos bens particulares deixados pelo falecido. Dessa forma, o legislador estaria retirando direitos de um lado e atribuindo-os de outro.

Nesse cenário, o problema que se coloca é de como aplicar a referida regra estampada no artigo 1829, I para os casos de união estável entre septuagenários, pois, a partir da declaração de inconstitucionalidade do artigo 1790 que regulava a sucessão dos companheiros, os ministros do STF entenderam pela aplicação das regras da sucessão do cônjuge também à sucessão do companheiro, mormente o artigo 1829, I. A partir dessa decisão, abre-se outra controvérsia: na união estável entre pessoas maiores de setenta anos deve ser aplicada a regra de separação obrigatória de bens prevista para o casamento entre septuagenários? Conforme narrado acima, entendemos que não. A união estável é forma livre de família reconhecida constitucionalmente, mas não é casamento. Por isso, parece um equívoco estender à união estável as regras atinentes ao casamento.

Nessa linha de raciocínio a situação se mostra muito controvertida e parece haver duas soluções possíveis. A primeira visa à aplicação das regras do casamento à união estável. Dessa forma, a união estável entre pessoas maiores de setenta anos também será regida pelo regime de separação obrigatória de bens, conforme entendimento atual da jurisprudência majoritária. Nesse caso, mantém-se a coerência legal entre as regras atinentes ao Direito de Família e ao Direito das Sucessões, pois, o companheiro sobrevivente não terá direito à herança do falecido quando concorrer com descendentes do autor da herança, nos termos do artigo 1829, I. Essa solução equipara as formas de família - casamento e união estável. Entretanto, conforme se concluiu acima, casamento e união estável são formas de família reconhecidas pela Constituição de 1988, mas não são iguais. Nas regras estampadas no Código Civil atinentes à união estável (artigos 1723 a 1727), o regime supletivo legal de bens eleito pelo legislador, foi o regime de comunhão parcial de bens, sem quaisquer ressalvas. Ao aplicar as regras concernentes ao casamento à união estável afasta-se as regras positivadas no diploma civil, sem que haja um fundamento hermenêutico para essa prática. Com efeito, aplica-se a analogia na ausência de regra legal, o que parece não ser o caso, pois as regras atinentes à união estável estão claramente reguladas no Código Civil. 
A segunda solução possível visa manter as regras da união estável conforme previstas no capítulo próprio do Código Civil (1723 a 1727), ou seja, na união estável sendo um ou ambos os conviventes maiores de setenta anos, mantém-se o regime de comunhão parcial de bens. Nesse caso, o companheiro sobrevivente participaria da sucessão do companheiro falecido, mesmo em concorrência com descendentes do autor da herança. Se por um lado essa solução satisfaz as regras atinentes ao Direito de Família, por outro, cria discrepância acerca das regras sucessórias. Com efeito, no casamento em que um ou ambos os cônjuges forem maiores de setenta anos, aberta a sucessão, o sobrevivente será afastado da sucessão do cônjuge falecido enquanto na união estável em que um ou ambos os nubentes forem maiores de setenta anos, aberta a sucessão, o sobrevivente participará da sucessão do companheiro falecidos.

Percebe-se que a questão é controvertida e de difícil solução! Uma terceira hipótese na tentativa de solucionar a questão parece passar pela declaração de inconstitucionalidade do artigo 1641, II do Código Civil. Com efeito, não há razão alguma para permanência dessa regra no Código Civil. O legislador perdeu a oportunidade de extirpar essa regra do ordenamento jurídico quando promulgou a Lei 12.443/2010 alterando a idade para imposição do regime de bens de 60 para 70 anos. Não há razão para permanência dessa regra limitativa da autonomia da vontade ao impor regime de bens em razão da idade. Principalmente diante desse novo cenário em que se aplicam as regras sucessórias do casamento à união estável.

Não se mostra coerente haver tratamento diferente para os casos de sucessão de cônjuges e de companheiros septuagenários. Da mesma forma não é coerente aplicar as regras do casamento de septuagenários à união estável dos maiores de setenta anos em razão de ausência de previsão legal.

Por outro lado, entender que o maior de setenta anos não tem discernimento para escolher, livremente, o regime de bens na constituição da família (casamento ou união estável) é pressupor insanidade mental que não se presume apenas e tão somente em razão da idade, principalmente, ante a crescente expectativa de vida na qual o cidadão de setenta anos goza de saúde suficiente para fruir dos prazeres da vida ainda por longos anos. Nesse ponto, outra questão merece ser problematizada: os maiores de setenta anos não podem escolher o regime de bens no casamento, mas podem livremente testar! Ora, trata-se, igualmente, de disposição patrimonial com reflexos para os possíveis futuros herdeiros! Portanto, entendemos não haver razão para permanência dessa esdrúxula regra limitativa da autonomia 
da vontade que determina o regime de separação obrigatória de bens para o casamento de maiores de setenta anos.

\section{CONCLUSÃO}

O texto da atual Constituição da República operou profundas alterações no Direito Civil, mormente no ramo da família, alterando seus principais eixos diretivos, entre os quais, o reconhecimento da pluralidade das formas de família. Entretanto, o reconhecimento constitucional da união estável não tem o condão de equiparar essa forma de família ao casamento. Não obstante o status constitucional, trata-se, efetivamente, de formas de famílias diversas, recebendo o casamento tratamento privilegiado, tanto que o legislador constituinte delega à legislação ordinária a tarefa de facilitar a conversão da união estável em casamento.

Ainda que a doutrina majoritária entenda pela distinção dessas formas de família, a jurisprudência, frequentemente, as equipara com o objetivo de legitimar a aplicação das regras concernentes ao casamento à união estável, em nítido confronto às normas constitucionais e infraconstitucionais, o que ocorreu, inclusive, com a determinação pelo Supremo Tribunal Federal de aplicação das regras sucessórias do casamento à união estável em razão da declaração de inconstitucionalidade do artigo 1790 do Código Civil que regulava a sucessão entre os companheiros.

O legislador ordinário, ao regular as relações patrimoniais entre os companheiros, estabeleceu o regime de comunhão parcial de bens, não fazendo qualquer ressalva em relação aos septuagenários. Ainda assim, nossos tribunais vêm aplicando, por analogia à regra esculpida no artigo 1641, II do Código Civil, o regime de separação obrigatória de bens à união estável dos septuagenários.

Após a declaração de inconstitucionalidade do artigo 1790 do Código Civil pelo STF determinando a aplicação das regras sucessórias do casamento aos casos de união estável, a questão merece análise detida, pois, o regime de bens do casamento faz toda a diferença quanto ao direito sucessório do cônjuge (e agora também do companheiro) quando concorre com descendentes do autor da herança. Com efeito, conforme norma expressa no artigo 1829, I do Código Civil, o cônjuge sobrevivente casado sob o regime de separação obrigatória de bens não tem direito à herança quando concorre com descendentes do autor da herança. Essa regra se aplica agora, também, à união estável quando se impõe o regime de separação de 
bens à união estável sendo um dos conviventes maiores de setenta anos.

Portanto, se por um lado entendemos totalmente inaceitável a aplicação analógica das regras do casamento à união estável, seja por impossibilidade de interpretação extensiva de regras legais restritivas de direitos, seja pela não equiparação constitucional das duas formas de família, por outro lado, a não aplicação da imposição do regime de separação de bens na união estável dos septuagenários acarretaria discrepância quanto à sucessão do companheiro colocando-o em situação de extrema vantagem em relação ao cônjuge quando concorre com descendentes do autor da herança. Ressalta-se aqui a importância de haver harmonia entre os ramos do Direito Civil, mormente, entre o Direito de Família e o Direito Sucessório.

A partir do problema em análise, não obstante discordarmos da aplicação analógica das regras concernentes ao casamento à união estável, após a declaração de inconstitucionalidade da regra que dispunha acerca da sucessão dos companheiros - artigo 1790 do Código Civil - aplicando-se as regras sucessórias do casamento à união estável, somos forçados a aceitar a aplicação analógica da imposição do regime de separação de bens aos companheiros maiores de setenta anos para evitar discrepâncias e incoerências na aplicação da lei.

Noutro giro, entendemos que a vedação legal imposta à pessoa de terceira idade em escolher livremente o regime de bens que irá reger seu casamento (ou união estável) é flagrantemente inconstitucional, na medida em que atenta contra a liberdade individual, a isonomia e, numa análise mais profunda, contra o princípio fundamental da dignidade da pessoa humana, princípio este, informador e basilar do Estado Democrático de Direito Brasileiro.

Por conseguinte, mesmo nas relações matrimoniais em que há previsão legal à essa restrição, a regra não poderia ser aplicada, visto que eivada de inconstitucionalidade, conforme já decidido por alguns tribunais sob a forma de controle difuso de constitucionalidade.

O legislador infraconstitucional ao elaborar regras em total dissonância com a ordem constitucional - no caso em exame, o artigo 1641, II do Código Civil - pretende adentrar na esfera íntima das pessoas, sem suporte no plano constitucional, o que deve ser repudiado pelo judiciário através do controle de constitucionalidade, garantindo, dessa forma, uma ordem jurídica justa, legítima, ou seja, em harmonia com Constituição elaborada pelo povo.

Os princípios instituidores do Estado Democrático de Direito, previstos pela 
Constituição existem para serem cumpridos e não ignorados pelo ativismo judicial, caso contrário, não podemos nos entender inseridos num Estado Democrático de Direito, mas sim, num Estado Social, em que o Estado age conforme uma crença geral de bem estar aplicável à todos, como se houvesse um acordo mudo acerca do bom o do justo no seio da sociedade.

\section{REFERÊNCIAS}

ABAGNANO, Nicola. Dicionário de Filosofia. São Paulo: Martins Fontes, 2007.

BRASIL. Superior Tribunal de Justiça. REsp. N 1171820/PR. 3 Turma. Min Rel. Sidnei Beneti. Publicado em 27.04.2011.

BRASIL. Superior Tribunal de Justiça. REsp n. 154.896/RJ. 4. Turma. Min. Relator Fernando Gonçalves, julgado em 20.11.2003.

BRASIL. Superior Tribunal de Justiça. REsp. n. 9.938/SP. 4 Turma. Min. Rel. Sálvio de Figueiredo Teixeira, julgado em 22.09.1992.

BRASIL. Superior Tribunal de Justiça. REsp. n. 123.633/SP. 4. Turma. Min. Rel. Aldir Passarinho Júnior, julgado em 17.03.2009.

BRASIL. Superior Tribunal de Justiça. REsp. n. 736627/PR. 3. Turma. Min. Rel. Carlos Alberto Menezes Direito, publicado em 01.08.2006.

BRASIL. Supremo Tribunal Federal. Recurso Extraordinário n. 878.694/MG. Relator Ministro Roberto Barroso. Publicado em 09.11.2018.

BRASIL. Supremo Tribunal Federal. Recurso Extraordinário n. 646.721/RS. Relator Ministro Marco Aurélio. Publicado em 27.02.2019.

DIAS, Maria Berenice. Manual de Direito das Famílias. 4 ed. São Paulo: RT, 2007. DIAS, Maria Berenice. Manual de Direito das Famílias. 11 ed. São Paulo: RT, 2016.

FARIAS, Cristiano Chaves de; ROSENVALD, Nelson. Direito das Famílias. v. VI. 3 ed. Rio de Janeiro: Lúmen Júris, 2011.

LEAL, Rosemiro Pereira. Processo como Teoria da Lei Democrática. Belo Horizonte: Fórum, 2010.

LEAL, Rosemiro Pereira. Teoria Processual da Decisão Jurídica. São Paulo: Landy, 2002.

MADALENO, Rolf. Curso de Direito de Família. Rio de Janeiro: Forense, 2008.

MATOS, Marlise. Reinvenções do vínculo amoroso: cultura e identidade de gênero na modernidade tardia. Belo Horizonte: UFMG; Rio de Janeiro: IUPERJ, 2000. 
MINAS GERAIS. Tribunal de Justiça. Apelação Cível 1.0702.06.317911-4/001. Relator:

Des. Sandra Fonseca. Minas Gerais, Belo Horizonte, 29 março 2011.

MINAS GERAIS. Tribunal de Justiça. Agravo de Instrumento $\mathbf{n}^{\mathbf{0}}$ 1.0216.13.004121-5/001, $7^{\mathrm{a}}$ Câmara Cível, Rel Des. Belizário de Lacerda. julgado em 10.03.0015, publicado em 17.03.2015.

NERY JUNIOR, Nelson. Princípios do processo na Constituição Federal. 9 ed. São Paulo: Revista dos Tribunais. 2009.

PEREIRA, Caio Mário da Silva. Instituições de Direito Civil. 27 ed. vol. V. Rio de Janeiro: Forense, 2019.

PEREIRA, Rodrigo da Cunha. Princípios fundamentais norteadores do direito de família. Belo Horizonte: Del Rey, 2006.

PEREIRA, Rodrigo da Cunha. Direito de família: uma abordagem psicanalítica. Belo Horizonte: Del Rey, 2003.

RIO GRANDE DO SUL. Tribunal de Justiça. Agravo de Instrumento n.

70017169335/Porto Alegre. Oitava Câmara Cível Des. Rel. José Ataídes Siqueira Trindade. Publicado em: 05.03.10.

SÃO PAULO, Tribunal de Justiça. Agravo de Instrumento no 2230760-84.2018.8.26.0000. $5^{\text {a }}$ Câmara de Direito Privado, Rel. James Siano, julgado em 12.02.2019.

TEPEDINO, Gustavo. Temas de Direito Civil. 4 ed. Rio de Janeiro: Renovar, 2008.

VENOSA, Sílvio de Salvo. Direito Civil. Família. 18 ed. vol. V. São Paulo: Atlas, 2018.

VILLELA, João Baptista. Liberdade Família, in Revista da Faculdade de Direito da UFMG. v.7. Belo Horizonte.1980. 